\title{
INLAMMATION, OXIDATIVE STRESS AND SYSTEMIC EFFECTS IN MILD CHRONIC OBSTRUCTIVE PULMONARY DISEASE
}

\author{
M.P. FOSCHINO BARBARO', G.E. CARPAGNANO', A. SPANEVELLO ${ }^{1,2}$, \\ M.G. CAGNAZZO' ${ }^{1}$ and P.J. BARNES ${ }^{3}$
}

'Instinte of Respiratory Disease, Department of Medical and Occupational Sciences, University of Foggia: 'Fondazione Salvatore Maugeri, Care and Research Institute, Cassano delle Murge, Bari, Italy;

${ }^{3}$ Dept. of Thoracic Medicine, National Heart and Lung Institute, Imperial College, London, UK

\section{Received February 23, 2007 - Accepted September 12, 2007}

Chronic obstructive pulmonary diseases (COPD) is a pulmonary disease characterized by systemic abnormalities. The aim of this study is to investigate inflammation and systemic effects in mild COPD. Twenty-seven mild stable smoking related COPD patients and 15 age-matched healthy subjects were enrolled in the study. IL-6, TNF- $\alpha$ and IL-4 in plasma, sputum and exhaled breath condensate were measured. We also measured exhaled nitric oxide (NO) and $\mathrm{pH}$ in sputum and in breath condensate. More ver, fat-free mass, body mass index (BMI), respiratory muscle strength, plasma oxidative stress and (-reactive protein (CRP) were measured. Higher concentrations were found of CRP, of diacron reactive oxygen metabolites (DROMs) and of IL-6, TNF- $\alpha$ and $I L-4$ either in plasma or in supernatant of inc uced sputum or in exhaled breath condensate of COPD subjects compared to healthy controls. Furthermore, higher concentrations were observed of exhaled $\mathrm{NO}$ and lower exhaled $\mathrm{pH}$ in breath condensate of COPD when compared with healthy subjects. In the group of COPD patients, the subjects with airway reversibility showed an increase of sputum eosinophils and exhaled NO, whereas the sıbjects without airway obstruction reversibility showed an increase in sputum neutrophils, TNF- $\alpha$ and $\mathrm{L}-6$. We also found a trend towards a decrease in fat-free mass and respiratory muscle strength in COPD compared to healthy subjects and a negative correlation between these systemic indices (fatfree mass, maximal inspiratory pressure, maximal expiratory pressure) and TNF- $\alpha$ concentrations in the blood, sputum and breath condensate. We conclude that mild COPD subjects present an increase in inflammatory markers in blood and in airways of similar pattern and furthermore, the neutrophilic pattern of airway inflammation observed in the group of COPD subjects without an airway obstruction reversibility makes it more likely that systemic features are present.

( hronic obstructive pulmonary disease (COPD) is usually considered to be a pulmonary disease (1). However, recent studies have demonstrated several extrat-pulmonary abnormalities, particularly in more severely affected patients, that suggest the necessity of a wider definition of this disease (2). Several systemic features have been described in COPD patients, including systemic inflammation and oxidative stress, skeletal muscle dysfunction (SMD), weight loss, atherosclerosis and osteoporosis $(3-5)$. 
These systemic effects may have an adverse effect on the quality of life and may contribute towards the mortality of COPD (6-8). Systemic inflammation and oxidative stress appear to be risk factors for the majority of the systemic complications in COPD patients (9). Several hypotheses have been suggested to explain how pulmonary inflammation and oxidative stress may spill over into the systemic circulation (10-11). There may be a genetic predisposition in some COPD subjects to develop both systemic and pulmonary inflammation (12-13). However, to date the exact mechanisms through which pulmonary inflammation and oxidative stress result in systemic effects in COPD remain unknown $(2,9)$.

Moreover, increased reversibility to bronchodilators in COPD patients may share some of the features of asthma, such as eosinophilia (14-16) and increased exhaled nitric oxide (NO) (17). Recently, our group demonstrated that COPD subjects with reversible obstruction present lower oxidative stress in airways (18). These more reversible COPD patients may represent an intermediate group of patients between asthma and non-reversible COPD or may be COPD patients who also have concomitant asthma (19).

The aim of this study is to investigate airway inflammation and systemic effects in mild COPD when compared with a group of healthy subjects. In particular we measured interleukin (IL)-6, tumor necrosis factor (TNF)- $\alpha$ and interleukin (IL)- 4 in plasma, induced sputum and breath condensate, exhaled nitric oxide (NO), exhaled $\mathrm{pH}$, inflammatory sputum cells and plasmatic $\mathrm{C}$ reactive protein ( $\mathrm{PCR}$ ) to investigate airway and sistemic inflammation and fat-free mass, body mass index (BMI), respiratory muscle strength, plasma oxidative stress to study the systemic effects of COPD.

\section{MATERIALS AND METHODS}

\section{Stucly population}

Twenty seven mild stable ex-smoker COPD $(52 \pm 4$ yrs, $21 \mathrm{M}$, I3A.SA, FEV $1.9+0.4 \mathrm{Il} .75 .3 \pm 3.1 \%$ of predicted ) and 15 heallhy ex-smoker subjects (49+7 yrs, $12 \mathrm{M}$, BASAL $11: V, 2.6+0.61 t, 110.416 .1 \%$ of predicted) with no history of lung discase were studied (Table I). The diagnosis of (CIP) was bised on I:RS/ATS Giuidelines (1). All subjects were recruited from llac Respiratory Disease
Institute, University of Foggia, and writhen informed consent was obtained from all subjects. The study wiss approved by the Institutional Ethics Commitlec.

None of the COPD patients had a history of atsthma or atopy or positive skin prick test, or were sulfering from chronic congestive heart failure. All patients were in a stable condition at the time of the study and free from acute exacerbations of symptoms or upper respiratory tract infections in the 3 months preceding the study. Only mild COPD were selected to avoid the influence on systemic effects of overlapped conditions that often appear in advanced stages of COPD (cardiovasura disorders, respiratory failure and others).

Healthy subjects had no respiratory symptoms and no respiratory tract infection for $\geq 3$ months prior to the study. All COPD patients and healthy subjects enrolled were ex-smokers from at least 6 months preceding the study. COPD patients were enrolled during routine hospital visits. A full medical history was taken and general physical examination was performed. Patients then underwent lung function testing, skin prick test for common inhalant allergens, serum total IgE, artcrial blood gas analysis, laboratory tests, fat-free mass, maximal inspiratory pressure (PImax), maximum expiratory pressure (PEmax), exhaled NO measurement, blood and breath condensate and induced sputum collection. None of patients included was treated with oral steroids and only short-acting inhaled $\beta_{2}$-agonists were allowed for symptom relief.

\section{Study design}

On the first day subjects underwent clinical data collection, physical analysis, lung function, fat free mass and respiratory muscle strength measurements and blowi tests.

On the second day exhaled NO, exhaled breath condensate collection and sputum induction were performed.

\footnotetext{
Pulmonary function testing and assessment of airflow limitation

Pulmonary function tests were performed prior to the measurement of exhaled breath condensate. FEV $\mathrm{FVC}$ and $\mathrm{FEV} / \mathrm{FVC}$ ratio werc measured wing a dry spirometer (Vmax Spectra series, SensorMedics Corporation, Yorba Linda, California, USA). The highest value of three manoeuvres was expressed as a perientage of the predicted normal value. Reversible sirflow limitation were defined as an increase in $\mathrm{FEV}_{1}$ of $200 \mathrm{ml}$ and $/$ or $\geq 12 \%$ from bascline $30 \mathrm{~min}$ after inhalation a 200 $\mu \mathrm{g}$ of salbutamol (1).
}

Fat-fiere mass measurement

Fat-fice mass was determined by biocectric 
impedanis analysis (Bodystat 1500: Douglas, UK) (20).

\section{Respinathryuscle strength}

Respliatlory muscle strength was assessed by measurerent of mouth pressure at maximal static inspiratory and espiratory efforts from residual volume and total lung capacity, PImax (maximal inspiratory pressure) and PEmax (maximal expiratory pressure) against all obstructed mouthpiece with a small leak to minimize oral pressure artifacts (Spirovis, Cosmed S.R.L., Italy) (2!).

\section{Induced sputum}

Sputum was collected and processed according to the method of Spanevello et al (22). All sputum counts and measurements were performed blind to the clinical details. Dofinition of an adequate selected sputum was one in which there were fewer than $20 \%$ squamous cells and viability $>50 \%$. A specific enzyme immunoassay kit (Cayman (hemical, Ann Arbor, Michigan, USA) was used to measure TNF- $\alpha$ and IL- 6 concentrations in supernatant of induced sputum.

\section{Exhalcd breath condensate and assay}

Exhaled breath condensate (EBC) was collected by using the LcoScreen, (Jaeger, Wurzburg, Germany). The subjects breathed through a mouthpiece and a two-way non-rebreathing valve, which also served as a saliva trap. They were asked to breathe at a normal frequency and tidal volume, wearing a nose clip, for a period of $10 \mathrm{~min}$. If subjects lclt saliva in their mouth they were instructed to swallow it. Condensate, at least $1 \mathrm{ml}$, was collected as ice at $-20^{\circ} \mathrm{C}$, tronsferred to Eppendorf tubes and immediately stored at $-76 \mathrm{~m}$. Samples were analysed within 3 months from collection. To exclude saliva contamination amylase activity was analysed in EBC.

\section{Measwroment of exhaled NO}

A rapid-response chemiluminescence NO analyzer (model 280; Sicvers Instruments; Boulder, Colorado, USA) was used to quantify NO. Two-point calibrations were perfomed daily using 5.2-parts per million calibration gats. Exhaled $\mathrm{NO}\left(\mathrm{F}_{1} \mathrm{NO}\right)$ was measured using a previously described restricted breathing technique, which employed expiratory resistance and positive mouth pressure 10 chose the velum and exclude nasal NO, and a constant expiratory flow of $45 \mathrm{~mL} / \mathrm{s}$. The inhaled gas Was ambient ilir that was passed through a filter to reduce inhaled No concentrations to $<5$ parts per billion (ppb). Subjects inhated to total lung capacity, and exhaled whilc largeting a constant pressure of $20 \mathrm{~mm} \mathrm{Hg}$. Exhalations procecded timil a clear NO plateau of at least 3 s duration was achieved. Repeated exhalations were performed until three plateaus agreed within 5\% (23).

\section{IL-6. TNF-a and IL-4 measurements}

A specilic enzyme immunoassay kit (Cayman (hemical, $\Lambda \mathrm{nn}$ Arbor, Michigan, USA) was used to measure IL-6, TNF- $\alpha$ and IL-4 concentrations in plasma, supernatant of induced sputum and breath condensate. The intra-assay and inter-assay variability were $\leq 10 \%$ for each assay and the detection limit of the assays was 1.5 $\mathrm{pg} / \mathrm{ml}, 4 \mathrm{pg} / \mathrm{ml}$ and $20 \mathrm{pg} / \mathrm{ml}$, respectively. The coefficient of variation for IL- 6, TNF- $\alpha$, IL-4 and $\mathrm{pH}$ were $5.9 \%$; $3,3 \% ; 4.2 \%$ and $0.4 \%$ respectively. Reproducibility of exhaled IL- 6 , TNF- $\alpha$ and $\mathrm{pH}$ measurements were assessed in 10 non-smoking normal subjects.

\section{pH measurements}

A stable $\mathrm{pH}$ was achieved in all cases after deaeration/ decarbonation of supernatant of induced sputum and breath condensate specimens by bubbling with argon ( 350 $\mathrm{ml} / \mathrm{min}$ ) for $10 \mathrm{~min}$, as previously described (24). $\mathrm{pH}$ was then measured within 5 minutes of condensate collection by means of a $\mathrm{pH}$ meter (Jenway-350, Ltd Gransmore Green, UK) with a 2 to $16.00 \mathrm{pH}$ range and a resolution/ accuracy on the order of $0.01 \pm 0.02 \mathrm{pH}$.

\section{Plasma reactive oxygen metabolites measurement}

Systemic oxidative stress was measured by the diacron reactive oxygen metabolites (D-ROM) test (Diacron International, Italy) (25). Values of DROMS were expressed as Carratelli Units, where 1 U.CARR corresponds to $0.8 \mathrm{mg} / \mathrm{L} \mathrm{H}_{2} \mathrm{O}_{2}$.

\section{Plasma CRP measurement}

Plasma CRP was measured using the $\mathrm{N}$ high sensitivity CRP Kit (Dade Berhing, Marburg, Germany) which has a lower limit of detection of $0.15 \mathrm{mg} / \mathrm{L}$.

\section{Statistical analysis}

Data are expressed as means \pm SD. A Mann-Whitney test was used to compare groups, and correlations between variables were performed using Spearman's rank correlation test. Significance was defined as a $p$ value of $<0.05$.

\section{RESULTS}

\section{Lung finction}

All ('OPD were defined as mild according to (jOLD guidelines (26). COPD subjects showed lower percentages of $\mathrm{FEV}$, and $\mathrm{FEV} / \mathrm{FVC}$ ratio compared to healthy controls $(82.6 \pm 1.5$ and $65.8 \pm 2.2$ vs $110.6 \pm 7.1$ and $81.3 \pm 1.4 ; p<0.01$ and $p<0.005$ ) 


\section{Cells counts in Induced sputum}

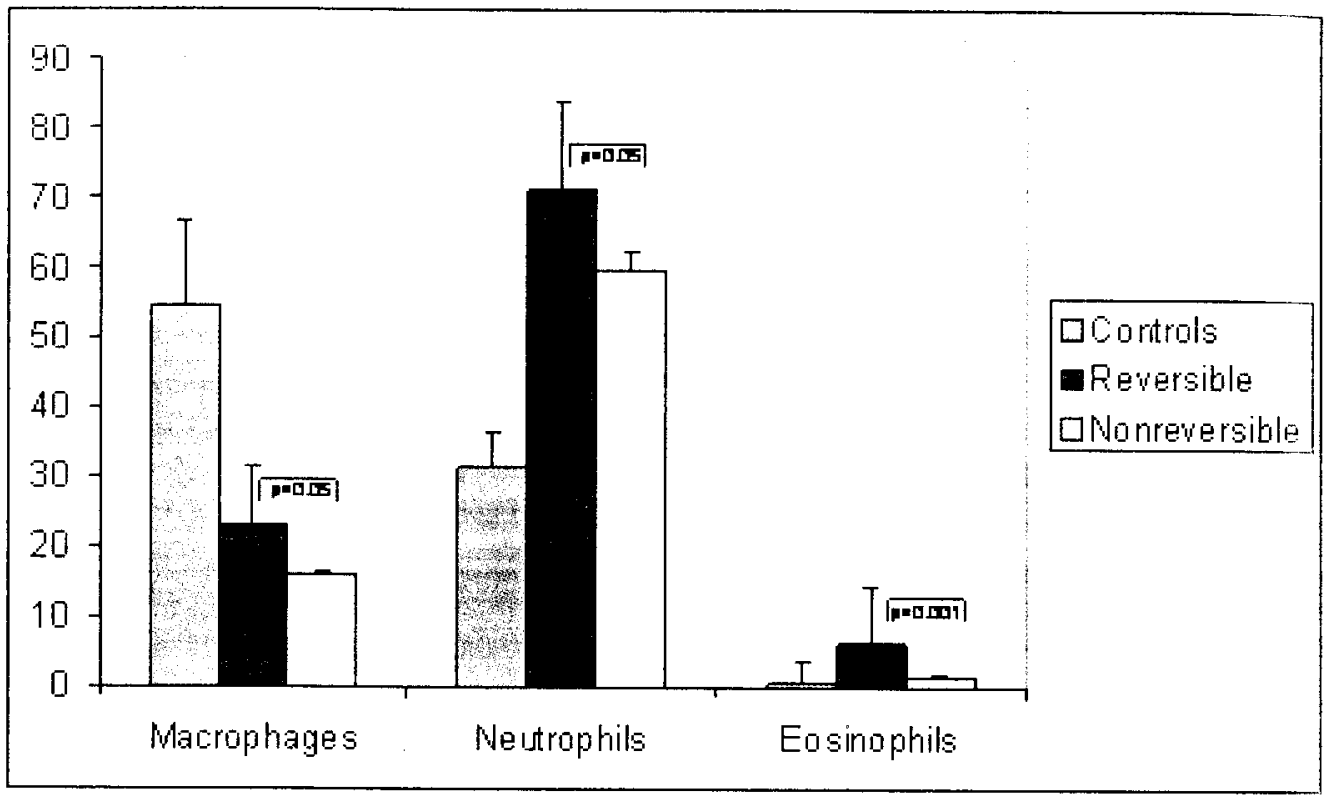

Fig. 1. Comparison between non-reversible COPD, reversible COPD and healthy controls in terms of percentage of cells found in the induced sputum. We observed a higher percentage of neutrophils in non-reversible COPD than in reversible and of eosinophils in reversible COPD than in non-reversible.

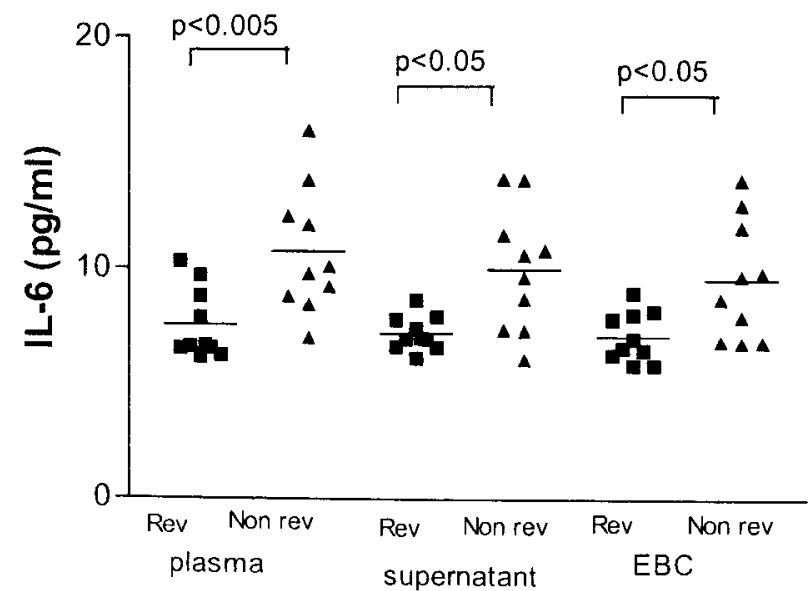

liig. 2. Concenrations of $I L-6$ in COPD subjects and heallhy combrols in plasma, supernatant of induced sputum and crhaled breath cendensate. We found elevated levels

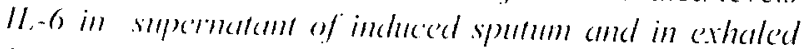

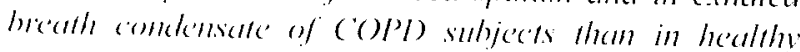

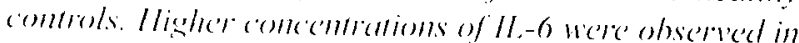

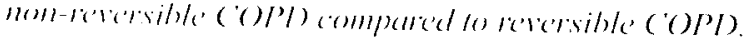

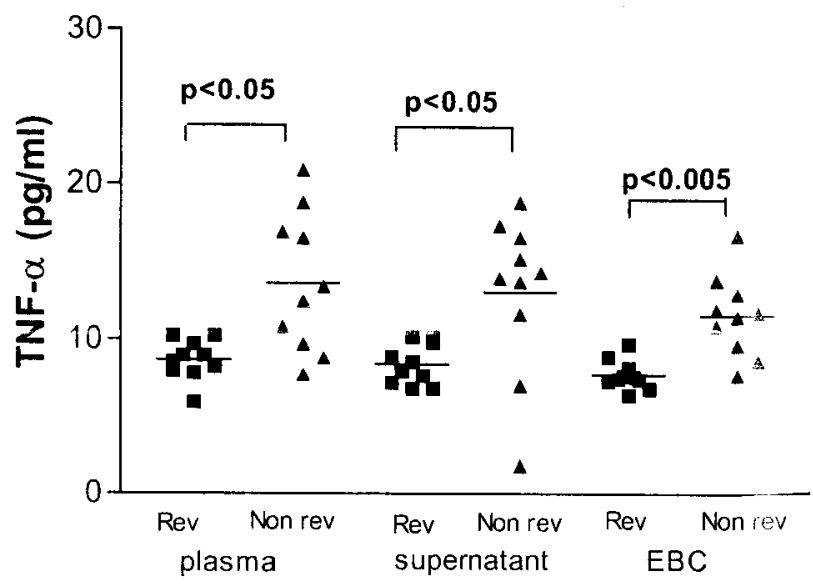

Fig. 3. Concentrations of TNF- $\alpha$ in COPD subjects and healthy controls in plasma, supernatant of indaced sputum and exhaled breath condensate. We found elevated levels $T N F-\alpha$ in stupernatant of induced sputum and in exhaled breath condensate of COPD sulyects than in healihy controls. Higher concentrations of TNF-a were obsered in non-revershle (OPD compared to reversible (OPD) 


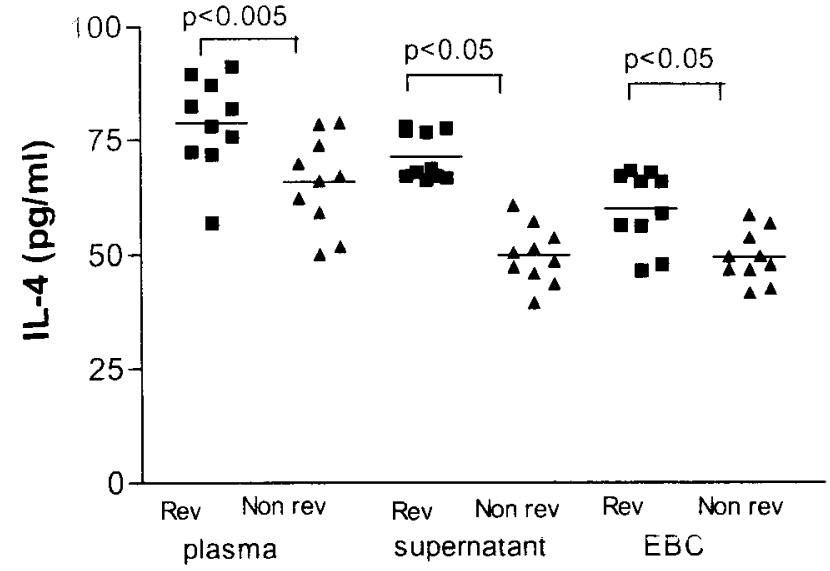

Fig. 4. Concentrations of $I L-4$ in COPD subjects and heilthy controls in plasma, supernatant of induced sputum and exhaled breath condensate. We found elevated levels $I L-4$ in supernatant of induced sputum and in exhaled breath condensate of COPD subjects than in healthy controls. Higher concentrations of $I L-4$ were observed in reversible COPD compared to non-reversible COPD.

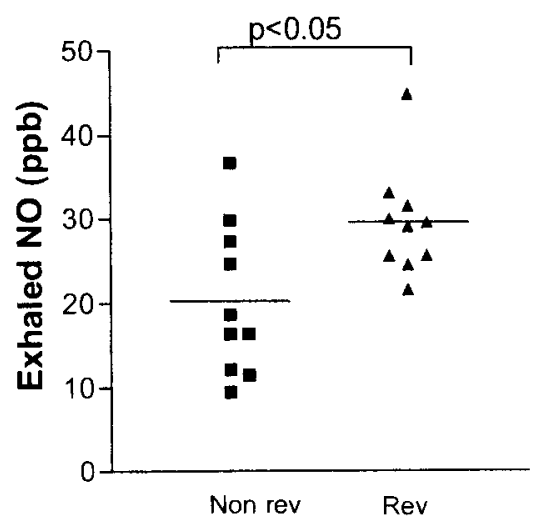

Fig. 5. Concentrations of exhaled nitric oxide (NO) in COPD subjects and healthy controls. Elevated concentrations of exhaled NO were observed in COPD pitients compared to control subjects and in reversible compared to non-reversible COPD.

( lable I). After reversibility test with salbutamol $(400 \mathrm{mcg})$ required for classification of (COPD by guidelines, $10 \mathrm{COPD}$ (mean age $53 \pm 3, \mathrm{FEV}$, $83.5 \pm 1.4$, pack/years $30.8 \pm 4.9$ ) had a reversibility $12 \%$ and 17 had a reversibility $<12 \%$ (mean age $55 \pm 5, \mathrm{FEV}, 85.1 \pm 1.5$, pack/years $31 .(0 \pm 45.1)$.

\section{Sputum measurements}

Sputum induction was performed in all subjects without observing any significant adverse effect or a decrease in $\mathrm{FEV}_{1}>20 \%$. Four healthy subjects and 6 COPD patients did not produce adequate sputum samples, and their expectorates were discarded. Table II and Fig. I show the comparison between the three groups in term of percentage of cells found in the induced sputum.

Higher percentages were found of neutrophils and eosinophils and a reduction of macrophages in COPD subjects $(66.4 \pm 8.8,4.6 \pm 1.1$ and $20.9 \pm 4.1 \%)$ than in healthy controls $(31.3 \pm 7.2,0.5 \pm 0.3$ and $54.7 \pm 6.5 \%)$

A higher percentage was observed of neutrophils in non-reversible COPD than in reversible (71.0 99.5 and $59.6 \pm 8.6 \%, \mathrm{p}<0.05)$ and of eosinophils in reversible COPD than in non-reversible $(6.3 \pm 1.1$ and $1.5 \pm 0.3 \%, \mathrm{p}<0.05$ ).

Elevated concentrations of IL-6 $(8.54 \pm 2.02$ vs $5.41 \pm 0.87 \mathrm{pg} / \mathrm{ml}), \mathrm{TNF}-\alpha(11.17 \pm 3.41$ vs $6.22 \pm 0.82$ $\mathrm{pg} / \mathrm{ml}), \mathrm{IL}-4(60.34 \pm 10.66 \mathrm{vs} 41.41 \pm 5.97 \mathrm{pg} / \mathrm{ml})$ and lower $\mathrm{pH}(7.50 \pm 0.06$ vs $7.86 \pm 0.18)$ were found in supernatant of induced sputum of COPD subjects than in healthy controls (Figures 2-4). Higher concentrations of IL-6 $(10.39 \pm 2.28$ vs $7.21 \pm 0.73$ $\mathrm{pg} / \mathrm{ml})$ and TNF- $\alpha(14.51 \pm 3.32 \mathrm{vs} 8.37 \pm 1.32 \mathrm{pg} / \mathrm{ml})$ were observed in supernatant of sputum of nonreversible and of IL-4 (71.24 \pm 5.27 vs $49.94 \pm 6.29$ $\mathrm{pg} / \mathrm{ml}$ ) of reversible COPD patients (Figures 2-4). Lower values of $\mathrm{pH}$ were found in non-reversible compared to reversible COPD $(7.48 \pm 0.07$ vs $7.52 \pm 0.05)$.

\section{Exhaled breath condensate measurements}

Elevated concentrations of IL-6 $(8.30 \pm 1.94$ vs $4.18 \pm 0.63 \mathrm{pg} / \mathrm{ml}), \mathrm{TNF}-\alpha(9.53 \pm 2.35$ vs $5.65 \pm 0.99$ $\mathrm{pg} / \mathrm{ml}), \mathrm{IL}-4(55.15 \pm 7.88$ vs $34.83 \pm 5.79 \mathrm{pg} / \mathrm{ml})$ and a lower $\mathrm{pH}(7.46 \pm 0.08$ vs $7.68 \pm 0.23)$ were found in exhaled breath condensate of COPD subjects compared to healthy controls (Table I).

Higher concentrations of IL- $6 \quad(9.49 \pm 2.55$ vs $7.08 \pm 1.07 \mathrm{pg} / \mathrm{ml})$ and TNF- $\alpha(11.51 \pm 2.60 \mathrm{vs}$ $7.72 \pm 0.68 \mathrm{pg} / \mathrm{ml})$ and lower concentrations of IL-4 $(49.49 \pm 5.56$ vs $60.07 \pm 8.13 \mathrm{pg} / \mathrm{ml})$ were obscrved in exhaled breath condensate of nonreversible compared to reversible COPD (Fig. 2-4). Lower levels of $\mathrm{pH}$ were found in exhaled breath condensate of reversible compared to non-reversible 
Table I. (haracteristics of (OPl) and healthy subjects

\begin{tabular}{|c|c|c|c|}
\hline & (C)PD ex-smokers $(11.27)$ & $\begin{array}{l}\text { Heallhy subjocts cx- } \\
\text { smokers (11.15) }\end{array}$ & p \\
\hline $\mathrm{Sex}(\mathrm{MH})$ & 24,3 & $12 / 3$ & $\cdots$ \\
\hline Smoke halbil (pack/yrs) & 30.315 .0 & 10.61 .32 & 0.001 \\
\hline BMI $\left(\mathrm{kg} / \mathrm{m}^{2}\right)$ & 21.112 .4 & $24.5 \pm 2.6$ & ns \\
\hline FEV & $82.6 \pm 1.6$ & 110.4 .6 .1 & 00.01 \\
\hline FEV,$/ F V C \%$ & $65.8 \pm 2.2$ & $81.3 \pm 1.4$ & $<0.005$ \\
\hline $\lg \mathrm{E}(\mathrm{kU} / \mathrm{L})$ & $13 \pm 4$ & $11 \pm 7$ & ns. \\
\hline Skin prick lest & negative & negative & \\
\hline $\mathrm{PaO}_{2}(\mathrm{mmHg})$ & $74.4 \pm 3.9$ & $75.4 \pm 2.4$ & ns \\
\hline $\mathrm{PaCO}_{2}(\mathrm{mmHg})$ & $37.9 \pm 2.5$ & $40.1 \pm 1.7$ & ns \\
\hline White blood cells $\left(\times 10^{\circ} / 1\right)$ & $7.9 \pm 1.9$ & $5.4 \pm 1.2$ & $<0.01$ \\
\hline Blood cosinophils $\left(\times 10^{9} / 1\right)$ & $0.41 \pm 0.26$ & $0.23 \pm 0.15$ & $<0.01$ \\
\hline $\operatorname{CRP}(\mathrm{mg} / \mathrm{l})$ & $11.55 \pm 11.11$ & $0.7 \pm 0.9$ & $<0.001$ \\
\hline Fat-free mass $(\mathrm{kg})$ & $46.42 \pm 4.49$ & $53.5 \pm 8.8$ & $<0.05$ \\
\hline PImax $\left(\mathrm{cm} \mathrm{H}_{2} \mathrm{O}\right)$ & $-65.55 \pm 20.88$ & $-105.8 \pm 2.4$ & $<0.001$ \\
\hline PEmax $\left(\mathrm{cm} \mathrm{H}_{2} \mathrm{O}\right)$ & $54.78 \pm 23.52$ & $192.5 \pm 6.7$ & $<0.001$ \\
\hline DROM (U.CARR) & $267.8 \pm 34.12$ & $36.8 \pm 6.0$ & $<0.001$ \\
\hline Exhaled NO (ppb) & $24.97 \pm 7.94$ & $9.07 \pm 1.64$ & $<0.001$ \\
\hline Plasma IL-6 (pg/ml) & $9.18 \pm 2.31$ & $5.82 \pm 0.89$ & $<0.001$ \\
\hline Sputum IL-6 (pg/ml) & $8.54 \pm 2.02$ & $5.41 \pm 0.87$ & $<0.001$ \\
\hline Condensate IL-6 $(\mathrm{pg} / \mathrm{ml})$ & $8.30 \pm 1.94$ & $4.18 \pm 0.63$ & $<0.001$ \\
\hline Plasma TNF- $\alpha(\mathrm{pg} / \mathrm{ml})$ & $11.22 \pm 3.67$ & $6.0 .6 \pm 1.55$ & $<0.001$ \\
\hline Sputum TNF- $\alpha(\mathrm{pg} / \mathrm{ml})$ & $11.17 \pm 3.41$ & 6.2210 .82 & 0.001 \\
\hline $\begin{array}{l}\text { Condensilte TNF- } \alpha \\
(\mathrm{py} / \mathrm{ml})\end{array}$ & $9.53 \pm 2.35$ & $5.65 \pm 0.99$ & $<0.001$ \\
\hline Plasma IL-4 (pg/ml) & $72.43 \pm 10.43$ & $38.71 \pm 5.33$ & 40.001 \\
\hline Spulum IL-4 (pg/ml) & $60.34 \pm 10.60$ & $41.41 \pm 5.97$ & $<0.001$ \\
\hline Conclensale IL-4 (pg/ml) & $55.15 \pm 7.88$ & $34.83 \pm 5.79$ & $<0.001$ \\
\hline Sputum pH & $7.50+0.06$ & $7.86 \pm 0.18$ & 60.05 \\
\hline Condensite pH & $7.46+0.08$ & $7.68+0.23$ & 0.05 \\
\hline
\end{tabular}

Data are shown as meamt SD). P= s/atistical comparison. A Mann-Whitney test was ased to compare groups

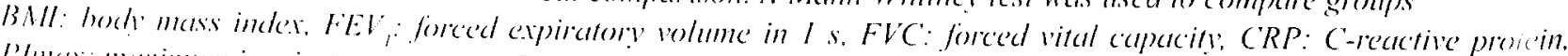

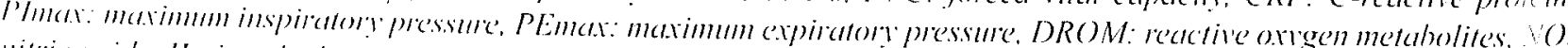

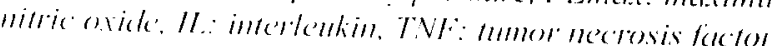


Table 11. Total and differential cell counts in induced sputum. Comparison be'ween paticnts with reversible (rolpl), patients with non-reversible COPD and healthy subjects in terms of pereentrge of cells found in the induced sputum. A significantly higher percentage was observed of neutrophils in non-reversihle COPD than in reversible and of cosinophils in reversible COPD than in non-reversible.

\begin{tabular}{|c|c|c|c|}
\hline & $\begin{array}{l}\text { Reversible } \\
\text { COPD }\end{array}$ & $\begin{array}{l}\text { Non- } \\
\text { reversible } \\
\text { COPD }\end{array}$ & Healthy subjects \\
\hline $\begin{array}{l}\text { Total cell count } \\
\left(\times 10^{6} / \mathrm{ml}\right)\end{array}$ & $2.9 \pm 0.6$ & $3.2 \pm 0.8$ & $2.6 \pm 0.6$ \\
\hline Macrophages (\%) & $23 \pm 4.9$ & $16 \pm 3.2$ & $54.5 \pm 6.7$ \\
\hline Neutrophils (\%) & $59.6 \pm 8.5^{*}$ & $71.0 \pm 9.6^{* *}$ & $31.4 \pm 7.1$ \\
\hline Eosinophils (\%) & $6.3 \pm 1.2 * *$ & $1.5 \pm 0.3$ & $0.5 \pm 0.2$ \\
\hline Lymphocytes (\%) & $0.9 \pm 0.5$ & $2.3 \pm 0.5$ & $1.1 \pm 0.6$ \\
\hline Epithelial cells (\%) & $9.1 \pm 2.4$ & $10.1 \pm 4.3$ & $11.1 \pm 3.8$ \\
\hline
\end{tabular}

Reversible COPD vs non-reversible COPD: ${ }^{*} p<0.05 ;{ }^{*} p<0.01$

COPD (7.43 \pm 0.07 vs $7.49 \pm 0.06$ ) (Fig. 2-4). Elevated concentrations of exhaled NO were observed in COPD patients compared to control subjects $(24.97 \pm 7.94$ vs $9.07 \pm 1.64 \mathrm{ppb})$ and in reversible compared to non-reversible COPD $(29.59 \pm 6.41$ vs $20.3 \pm 8.9 \mathrm{ppb}$ ) (Table I and Fig. 5).

\section{Systemic measurements}

A significant reduction of a fat free mass (46.4 \pm 24.49 vs $53.5 \pm 8.8 \mathrm{~kg}$ ), of PImax (-65.55 20.88 vs $\left.105.8 \pm 2.4 \mathrm{cmH}_{2} \mathrm{O}\right)$ and PEmax $(54.78 \pm 23.52$ vs $192.5 \pm 6.7 \mathrm{cmH}_{2} \mathrm{O}$ ) was observed in COPD patients compared to healthy subjects (Table I). COPD patients also showed higher concentrations of white blood cells $\left(7.9 \pm 1.9\right.$ vs $\left.5.1 \pm 1.3 \times 10^{9} / 1\right)$, blood eosinophils $\left(0.41 \pm 0.26\right.$ vs $\left.0.23 \pm 0.15 \times 10^{\circ} / \mathrm{l}\right)$ and CRP $(11.55 \pm 11.11 \mathrm{vs} 0.7 \pm 0.9 \mathrm{mg} / \mathrm{l})$ than healthy subjects. We also observed a reduction of BMI $(21.0 \pm 2.4$ vs $24.5 \pm 2.6 \mathrm{~kg} / \mathrm{m}^{2}$ ) between COPD patients and control subjects, although this did not achieve significance.

\section{Plasma concentrations}

Higher concentrations of DROMs $(267.8 \pm 34.12$ vs $36.8 \pm 6.0$ U.CARR), IL-6 ( $9.18 \pm 2.31$ vs $5.82 \pm 0.89$ $\mathrm{pg} / \mathrm{ml}), T N F-\alpha(11.22 \pm 3.67 \mathrm{vs} 6.06 \pm 1.55 \mathrm{pg} / \mathrm{ml})$ and IL-4 $(72.43 \pm 10.43 \mathrm{vs} 38.71 \pm 5.33 \mathrm{pg} / \mathrm{ml})$ were found in plasma of COPD patients compared with healthy subjects (Table I).

The plasma levels of IL- 6 and TNF- $\alpha$ were higher in non-reversible COPD (10.72 \pm 2.72 vs $7.57 \pm 1.52$ $\mathrm{pg} / \mathrm{ml}$ and $13.57 \pm 4.49$ vs $8.66 \pm 1.29 \mathrm{pg} / \mathrm{ml}$ ) whereas the levels of IL- 4 were higher in reversible COPD ( $78.66 \pm 10.22$ vs $65.72 \pm 10.03 \mathrm{pg} / \mathrm{ml}$ ) when compared to healthy subjects (Fig. 2-4).

\section{Correlations}

The relations between the fat-free mass with the inflammatory markers were studied using the Spearman's rank correlation test, finding negative correlations between fat-free mass and TNF- $\alpha$ in plasma $(p<0.001, r=-0.83)$, TNF $-\alpha$ in supernatant of induced sputum $(\mathrm{p}<0.001, \mathrm{r}=-0.75)$, TNF- $\alpha$ in breath condensate $(\mathrm{p}<0.05, \mathrm{r}=-0.44)$ and between PImax, PEmax and TNF- $\alpha$ in plasma $(\mathrm{p}<0.01$, $r=-0.61 ; p<0.01, r=-0.64), \quad T N F-\alpha$ in supernatant of induced sputum $(p<0.05, r=-0.50 ; p<0.05, r=-$ $0.48), T N F-\alpha$ in breath condensate $(p<0.05, r=-0.53$; $\mathrm{p}<0.05, \mathrm{r}=-0.46$ ). Furthermore, a strong correlation was observed between PImax and fat-free mass $(\mathrm{p}<0.01, \mathrm{r}=0.67)$.

\section{DISCUSSION}

Several recent studies have investigated the inflammation in COPD and the possible mechanisms of its systemic effects (2-5). In agreement with previous studies we found significant increases in several inflammatory biomarkers (CRP, TNF$\alpha$, IL-6) $(9,27-37)$ and leukocytes $(9,27)$ in the peripheral blood of a group of ex-smoker COPD 
patients compared to age-matched healthy subjects. Moreover, we also measured the same inflammatory markers in the supernatant of the induced sputum and in breath condensate in order to compare with the pattern of pulmonary inflammation, and an increase was found in the concentrations of the same inflammatory markers in COPD patients compared to healthy subjects, indicating that in COPD patients pulmonary and systemic inflammation has a similar pattern (32).

Previous studies have characterized the pulmonary inflammation in COPD patients by measuring cells in induced sputum, and have shown an increase in eosinophils in reversible COPD compared to an increase of neutrophils in non-reversible COPD (17). We have confirmed these differences in our own study. We also found higher levels of IL- 6 and TNF$\alpha$ in plasma, in supernatant of the induced sputum and in breath condensate of non-reversible COPD, whereas we found higher levels of IL-4, which is usually associated with allergic inflammation, in patients with reversible COPD. This is the first time that IL-4 has been detected in supernatant of induced sputum and in breath condensate of COPD subjects. We also found higher levels of exhaled NO in COPD patients with reversible airflow limitation, in agreement with a previous study (17).

We also measured $\mathrm{pH}$ of the breath condensate and found lower values in COPD patients compared with healthy subjects, in agreement with a previous study (33). We also found a similar reduction in $\mathrm{pH}$ values in supernatant of induced sputum confirming acidification of the lower airways in COPD patients. No differences in $\mathrm{pH}$ were found between reversible COPD and non-reversible COPD, suggesting that both eosinophilic and neutrophilic inflammation could cause a decrease of $\mathrm{pH}$.

Several studies have highlighted nutritional abnormalities in COPD patients, including alterations in caloric intake, basal metabolic rate, intermediate metabolism and body composition (34-35). Moreover, alterations in body composition may occur in COPD in the absence of clinically significant weight-loss (36). In our study we found a decrease in fat-free mass in COPD patients compared with healthy subjects. We also found a lower fat-free mass in non-reversible COPD than in reversible (OPD, although this difference did not achieve statistical significance. We investigated a possible relation between fat-frec mass and inflammatory markers and found no correlation with IL-6 and IL-4, but a strong negative correlation between fat-free mass and TNF- $\alpha$ in plasma, sputum supernatant and in breath condensite. Previous reports have highlighted the potential role of TNF- $\alpha$ in inducing catabolic responses in tissues, triggering muscle proteolysis and increased protein degradation (37). Our findings suggest that there could be a relation between inflammation (local and/or systemic) and body composition in COPD patients and this relation, because of its significant correlation with TNF- $\alpha$, a mediator associated with neutrophilic inflammation, could be more important in non-reversible COPD patients. We found a similar trend in the values of PImax and PEmax: which were lower in non-reversible COPD (although this did not achieve significance) and there was a negative correlation between these measurements of muscle strength with TNF- $\alpha$ concentrations in plasma. This is not surprising as a decrease of fat-free mass can cause a decrease of the muscular strength and so a decrease in the values of the PImax and PEmax (6). Indeed, we confirmed a strong correlation between PImax and fat-free mass. The involvement of TNF$\alpha$ in the weight loss of COPD has already been investigated, while the other markers (CRP, IL-6) are more associated with cardiovascular complications (37-39).

Finally, we have confirmed a link between inflammation and oxidative stress, which may reflect increased transcription pro-inflammatory cytokine genes in response to reactive oxygen species (39). In COPD there is increased oxidative stress in exhaled breath and in plasma (40). In a previous study we described an increase of oxidative stress and oxidative protein damage in induced sputum of non-reversible COPD compared to reversible (18). In this study we found an increase of the value of plasma DROMs among the COPD patients, particularly among the non-reversible COPD patients, that is in line with our previous data on airways of non-reversible COPD and proved the presence of a concomitant systemic oxidative stress in these patients.

COPD is characterized by an intense inflammatory process in the airways, parenchyma 
and pulmonary vasculature, and this process may spill over into the systemic circulation, promoting a gencralised inflammatory reaction (31). Our study confirms previous studies of local and systemic inflammation in COPD patients, and distinguishes patterns of inflammation between reversible and non-reversible COPD. The similarity between the pattern and pulmonary inflammation (measured by induced sputum and exhaled breath condensate) and systemic markers of inflammation adds support to the idea that systemic effects arise from a spillover of inflammation from the lung. Furthermore, these systemic features more closely mimic the neutrophilic pattern of inflammation associated with non-reversible COPD, indicating that this form of COPD is more likely to be associated with systemic effects.

\section{ACKNOWLEDGEMENTS}

The aithors gratefully acknowledge Dr Falcone without whose dedicated and expert technical assistance this study would not have been possible.

\section{REFERENCES}

1. Celli B.R. and W. MacNee. 2004. ATS/ERS Task Force. Siandards for the diagnosis and treatment of patients with COPD: a summary of the ATS/ERS position paper. Eur. Respir. J. 23:932.

2. Agusti A.G.N., A. Noguera, J. Sauleda et al. 2003. Systemic effects of chronic obstructive pulmonary disease. Lirr: Respir. J. 21:347.

3. Anonymous. 1999. Skeletal muscle dysfunction in chronic obstructive pulmonary disease. A statement of the American Thoracic Society and European Respiralury Society. Am. J. Respir. Crit. Care Med. $159(\mathrm{~S}): 1$.

4. Schols A.M., J. Slangen, L. Volovics et al. 1998. Weight loss in a reversible factor in the prognosis of chronic ohstructive pulmonary discase. Am. J. Respir: (irit. Care Hed. 157:1791.

5. Augusti R.(..N. 2001. Systemic effects of Chronic obstructive pulmonary discase. In Chronic ohstructive pulmonary disease: pathogenesis to treatment. I). (hadwick, J.A. Goode, eds. John Wiley and Sons l. ld., Chichester, p. 242.
6. Rochester D.F. 1986. Malnutrition and the respiratory muscles. Clin. Chest. Med. 7:91.

7. Ketelaars C.A.J., M.A.G. Schlosser and R. Mosert. 1996. Determinants of health-related quality of life in patients with chronic obstructive pulmonary disease. Thorax 51:39.

8. Efthimiou J., J. Fleming, C. Gomes et al. 1988. The effect of supplementary oral nutrition in poorly nourished patients with chronic obstructive pulmonary disease. Am. Rev. Respir. Dis. 137:1075.

9. Gan W.Q., S.F.P. Man, A. Senthilselvan et al. 2004. Association between chronic obstructive pulmonary disease and systemic inflammation: a systematic review and meta analysis. Thorax 59:574.

10. van Eeden S.F., W.C. Tan, T. Suwa et al. 2001. Cytokines involved in the systemic inflammatory response induced by exposure to particulate matter air pollutants. Am. J. Respir. Crit. Care Med. 164: 826.

11. Fuji T., S. Hayashi, J.C. Hogg et al. 2002. Interaction of alveolar macrophages and airway epithelial cells following exposure to particulate matter produces mediators that stimulate the bone marrow. Am. J. Respir. Cell Mol. Biol. 27:34.

12. Pauwels R.A., A.S. Buist, P.M. Calverley et al. Global strategy for the diagnosis, management and prevention of chronic obstructive pulmonary disease: NHLBI/WHO global initiative for Chronic Obstructive Pulmonary Disease (GOLD).

13. Salvi S., A. Blomberg, B. Rudell et al. 1999. Acute inflammatory responses in the airways and peripheral blood after short term exposure to diesel exhaust in healthy human volunteers. Am. J. Respir. Crit. Care Med. 159:702.

14. Celli B.R., G.L. Snider, J. Heffner et al. 1995. Standards for the diagnosis and care of patients with chronic obstructive pulmonary disease: American Thoracic Society. Am. J. Respir: Crit. Care Med. 152(S):77.

15. Chanez P., A.M. Vignola, T. O'Shaugnessy et al. 1997. Corticosteroid reversibility in COPD is related to features of asthma, Am. J. Respir: (rit. Care Med. 155:1529.

16. D.-W. Perng, H.-Y. Huang, H.-M. Chen et al. 2004. Characteristics of airway inflammation and bronchodilator reversibility in COPD. ('hest /26:37.5. 
17. Papi ^., M. Romagnoli, S. Barldo et al. 2000). Partial reversibility of airflow limitation and increased exhaled NO and sputum cosinophilia in chronic obstructive pulmonary discase. Am. J. Respir: Crit. Care Med. 162:1773.

18. Serviddio G., G.E. Carpagnano, T. Rollo et al. 2006. Evidence of lower oxidative stress in the air spaces of patients with reversibile COPD. Int. I. Immun. Pharmac. 19(3):617.

19. Sitkauskiene B., R. Sakalauskas, K. Malakauskas et al. 2003. Reversibility to a B2-agonist in COPD: relationship to atopy and neutrophil activation. Respiratorv Med. 97:591.

20. Zhu S., Z. Wang, W. Shen et al. 2003. Percentage body tat ranges associated with metabolic syndrome risk: results based on the third National Health and Nutrition Examination Survey (1988-1994). Am. J. Clin. Nutri. 78:228.

21. Kutsuzawa T., S. Shioya, D. Kurita et al. 1992. ${ }^{31} \mathrm{P}-\mathrm{NMR}$ study of skeletal muscle metabolism in patients with chronic respiratory impairment. $\mathrm{Am}$. Rev. Respir. Dis. 146:1019.

22. Spanevello A., M. Confalonieri, F. Sulotto et al. 2000. Induced Sputum Cellularity. Am. J. Respir. Crit. Care Med. 162: 1172.

23. Silkoff P.E., D. Martin, J. Pak et al. 200 I. Exhaled nitric oxide correlated with induced sputum findings in COPD. Chest 119:1049.

24. Tate S., G. MacGregor, M. Davis et al. 2002. Airways in cystic fibrosis are acidified: detection by exhaled breath condensate. Thorax 57:926.

25. Parmigiani S., L. Gambini, A. Massari et al. 1997. Evaluation of reactive oxygen metabolities with micromethod in neonates: determination of standards of normality in full term babies. Acta Biomed. Ateneo Parmense 68:103.

26. Pauwels R.A., A.S. Buist, P.M. Calverley et al. 2001. GOLD Scientific Committce. Global strategy for the diagnosis, management, and prevention of chronic obstructive pulmonary disease. NHLBI/ WIIO (ilobal Initiative for Chronic Obstructive Lung Discase (GOLD) Workshop summary. Am. I. Respir: Crit. Core Med. 163:1256.

27. Mannino D.M., E.S. Ford and S.C. Redd. 2003. (Ohstructive and restriclive lung disease and markers of inllammation: Data from the herd national health and nutrition examination. $1 / 1,1 . \mathrm{ked} / 1 / 4.758$

28. Nguyen I.T., M. Bedu, 1). (aillaud et al. 1999. Increased resting energy expenditure is related to plasma TNF-alpha concentration in stable COPD paticnts. ( $/ \mathrm{in}$. Nutr. / $/ 8(5): 26)$

29. Secmungal T., R. Harper-ouren, A. Bhowmik et al. 2001. Respiratory viruses, symptoms, and inflammatory markers in acule cxacerbations and stable chronic obstructive pulmoniry disease. $\mathrm{Am}$.J. Respir: Crit. Care Med. 164:16/3.

30. Wedzicha J.A., T.A. Seemungal, P.K. MacCallum et al. 2000. Acute exacerbations of chronic obstructive pulmonary disease ane accompanied by elevations of plasma fibrinogen and serum IL-6 levels. Thromb. Haemost. 84:210,

31. Stankiewitz W., M.P. Dabrowski, A. Chcialowski et al. 2002. Cellular and cytokine immunoregulation in patients with chronic obstructive pulmonary disease and bronchial asthma. Medietors Inflamm. 11:307.

32. Carpagnano G.E., S.A. Kharitonow, O. Resta et al. 2003. IL-6 is increased in breath condensate of smokers. Eur. Respir. J. 21:589

33. Kostikas K., G. Papatheodorou, K. Ganas et al. 2002. $\mathrm{pH}$ in expired breath condensate of patients with inflammatory airway diseases. All. J. Respir. Crit. Care Med. 165(10):1364.

34. Wouters E.F.M. 2003. Introduction: systemic effects in chronic obstructive pulmonary discase. Eur. Respir. J. 22(S): I.

35. Yeh S., B. DeGuzman and T. Kramer. 2002. Reversal of COPD-associated weight loss using the anabolic agent oxandrolone. Chest 122:421.

36. Piitulainen E., J. Areberg, M. Linden et al. 2002. Nutritional status and muscle strength in patients with emphysema and severe alpha-antitrypsin deficiency. Chest 122:1240.

37. Reid M.B., J. Lannergren and H. Westerblad. 2002. Respiratory and limb muscle weakness induced by tumor necrosis factor-alpha: invols ement of muscle myofilaments. Am. J. Respir Crit. Care Med. 160:479.

38. Danesh J., R. Collins, P. Appleby et al. 1498. Association of fibrinogen, C reactive protein, albumin or leukocyte count with coronary heart diseasc: netaanalyses ol prospective studies. J/1M/279; /477. 
39. Pradhan A.D., J.E. Manson, J.E. Rossow et al. 2002. Inflammatory biomarkers, homone replacement therapy and incident coronary heart discase: prospective andysis from the Women's Health Initiative observational study. JAMA $28 \%$ : 980

40. Boots A.W., G.R.M.M. Haenen and A. Bast. 2003. Oxidant metabolism in chronic obstructive pulmonary discase. Eur: Respir: J. 22(S): 14. 